\title{
The exotic weevil Stenopelmus rufinasus Gyllenhal, 1835 (Coleoptera: Curculionidae) across a "host-free" pond network
}

\author{
Margarita Florencio ${ }^{1,2, *}$, Rocío Fernández-Zamudio ${ }^{1}$, David T. Bilton ${ }^{3}$ and Carmen Díaz- \\ Paniagua $^{1}$ \\ ${ }^{1}$ Estación Biológica de Doñana (CSIC), Sevilla, Spain. \\ 2 Present address: Azorean Biodiversity Group (CITA-A) and Platform for Enhancing Ecological Research and \\ Sustainability (PEERS), Departamento de Ciências Agrárias, Universidade dos Açores, Azores, Portugal. \\ ${ }^{3}$ Marine Biology and Ecology Research Centre, Plymouth University, Drake Circus, Plymouth PL4 8AA, UK. \\ * Corresponding author: margarita@ebd.csic.es
}

Received: 18/06/2014 Accepted: 01/12/2014

\begin{abstract}
The exotic weevil Stenopelmus rufinasus Gyllenhal, 1835 (Coleoptera: Curculionidae) across a "host-free" pond network

The presence of the exotic weevil Stenopelmus rufinasus (Coleoptera: Curculionidae) is closely related to the occurrence of the exotic red water fern, Azolla filiculoides. In this paper, we present the first records of S. rufinasus in Doñana National Park (SW Spain), based on sampling of macroinvertebrates in 91 temporary ponds, including monthly samples of 22 ponds, during two successive years (2005-2007). The exotic weevil was present in $21 \%$ of the sampled ponds where the host plant, $A$. filiculiodes, was not detectable. Because A. filiculoides can reach high densities in an adjacent area of marsh, we suggest that the occurrence of the exotic weevil in these ponds is a consequence of dispersal from nearby marshes. Our study demonstrates that $S$. rufinasus adults can occur at relatively high densities in ponds where the host plant is not present, suggesting that such apparently "host-free" sites may act as stepping stones for the spread of this species.
\end{abstract}

Key words: Azolla, Stenopelmus, exotic species, Doñana, freshwaters, marshes, temporary ponds.

\section{RESUMEN}

Presencia del gorgojo exótico Stenopelmus rufinasus Gyllenhal, 1835 (Coleoptera: Curculionidae) en un sistema de lagunas libre de hospedadores

La presencia de la especie de gorgojo exótico Stenopelmus rufinasus (Coleoptera: Curculionidae) está íntimamente relacionada con la planta acuática exótica Azolla filiculoides. En este estudio se registró por primera vez la presencia de $\mathrm{S}$. rufinasus en el Parque Nacional de Doñana (SO España) tras realizar un muestreo de macroinvertebrados en 91 lagunas que incluye muestreos mensuales de 22 de las mismas durante dos años consecutivos (2005-2007). El gorgojo exótico estuvo presente en el $21 \%$ de las lagunas muestreadas a pesar de que su supuesto hospedador, A. filiculiodes, no fue detectado. Dado que A. filiculiodes puede alcanzar grandes densidades en la marisma adyacente, sugerimos que la presencia del gorgojo exótico en las lagunas temporales se debe a su dispersión desde la marisma. Este estudio demuestra que individuos adultos de S. rufinasus pueden aparecer con densidades relativamente altas en lagunas donde su hospedador potencial no está presente, lo que sugiere que estos sitios libres de hospedador podrían actuar como zonas de paso para la dispersión de la especie

Palabras clave: Azolla, Stenopelmus, especies exóticas, Doñana, humedales, marisma, lagunas temporales. 


\section{INTRODUCTION}

The aquatic weevil Stenopelmus rufinasus Gyllenhal 1835 (Coleoptera: Curculionidae) is native to North America. It was first recorded in Europe (France) in 1898 (Bedel, 1901), expanding in only a few years to the United Kingdom and the Netherlands (http://www.gbif.org). Currently, this exotic weevil is quite widespread in Europe and has also been recorded in Ireland, Germany, Belgium, Italy, Spain and the Ukraine (Pan-European Species directories Infrastructure, PESI). The introduction of $S$. rufinasus to Europe is most likely related to the arrival of the exotic red water fern, Azolla filiculoides (Lamark 1783 ), as an ornamental plant in the mid-19 $9^{\text {th }}$ century (Sculthorpe, 1967). This water fern is native to the southern and western USA and is currently distributed across most countries in Europe (Delivering Alien Invasive Species Inventories for Europe, http://www.europe-aliens.org) as a harmful invasive alien species, causing high impacts on biodiversity in freshwater ecosystems (European Alien Species Information Network, http://easin.jrc.ec.europa.eu). The life cycle of $S$. rufinasus is strongly linked to Azolla ferns, the typical host plant in which this weevil oviposits. After emergence, the larvae feed on Azolla leaves for 4-7 days until pupation, producing an amphibious imago (Richerson \& Grigarick, 1967).

This exotic weevil was first detected on the Iberian Peninsula in 2002 (Fernández Carrillo et al., 2005). It was found in the surroundings of Doñana National Park in 2003 (Dana \& Viva, 2006). In 2001, the presence of A. filiculoides was first reported in Doñana National Park (García-Murillo et al., 2007), where the fern can reach high densities in the marshes (FernándezZamudio, 2011). Doñana National Park has a high conservation status. It has been included in the RAMSAR convention since 1982 and was designated a World Heritage Site in 1995 by UNESCO.
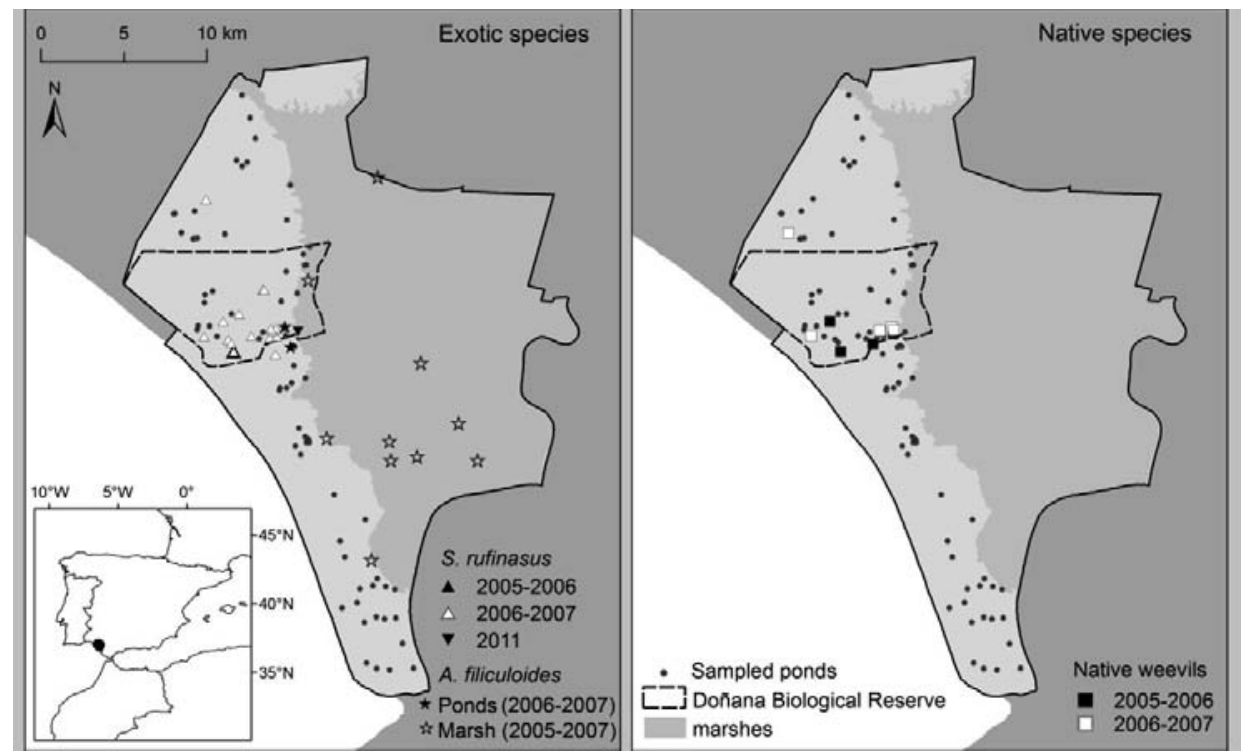

Figure 1. Distribution of the exotic weevil (Stenopelmus rufinasus) and the three species of native weevils in 91 ponds sampled across Doñana National Park. The boundaries of the Doñana Biological Reserve, the sampling period considered (2005-2006, 20062007 and 2011), those sampling sites in the marsh where the biomass of Azolla filiculoides was sampled and those ponds in which A. filiculoides was detected (only detected in 2006-2007) are also indicated (see Appendix 1 for detailed geographical coordinates). Distribución del gorgojo exótico (Stenopelmus rufinasus) y de las tres especies de gorgojos nativos en las 91 lagunas muestreadas en el Parque Nacional de Doñana. Se indican los límites de la Reserva Biológica de Doñana, el periodo de muestreo considerado (20052006, 2006-2007 y 2011), los puntos de la marisma donde se realizaron los muestreos de biomasa de Azolla filiculoides y aquellas lagunas donde A. filiculoides fue detectada (sólo detectada en 2006-2007) (ver el Apéndice 1 para las coordenadas geográficas detalladas). 
In this study, we first report the presence of this exotic weevil in Doñana National Park and note its distribution in a natural pond network in which A. filiculoides appears only occasionally.

\section{METHODS}

\section{Study area}

We sampled 91 ponds distributed across Doñana National Park (Fig. 1, see Table S1 for detailed geographical coordinates at www.limnetica.net/internet) to analyse the macroinvertebrate composition of the pond network. This area is located between the mouth of the Guadalquivir River and the Atlantic Ocean in southwest Spain. In this area, numerous temporary ponds are located on stable dunes adjacent to an extensive marsh. Ponds vary greatly in size and permanence; temporary ponds are flooded after heavy rains, usually filling in autumn or winter, and persist until late spring or early summer.

\section{Sampling procedure}

We compiled data from two types of samples: i) macroinvertebrate sampling performed from mid-March to mid-June 2007 in a total of 91 ponds encompassing a wide range of hydroperiods (Fig. 1; see Florencio et al., 2011 for details); ii) monthly macroinvertebrate sampling of 22 ponds located in a Biological Reserve in the centre of the Park (Fig. 1) across two complete annual cycles of inundation to desiccation (October 2005-August 2007; see Florencio et al., 2009 for details). The use of a standardised sampling process for macroinvertebrates allowed us to compare exotic and native weevils between ponds differing in habitat heterogeneity and environmental variables, e.g., pond depth and surface area. The specimens recorded were preserved in $70 \%$ ethanol and identified by one of the authors (DTB). Records of exotic weevils in 2011 were also considered to confirm its occurrence in the marsh. Aquatic plants were also visually recorded in each sampling unit; special attention was paid to the presence of $A$. filiculoides.

\section{Biomass of the exotic red water fern}

The biomass of $A$. filiculoides was obtained from monthly sampling of 10 different localities across the marsh area during the study period. Three different replicates of a $0.03 \mathrm{~m}^{2}$ area were sampled at each locality. Plants were dried at $75^{\circ} \mathrm{C}$ until a constant dry weight was obtained (see Fernandez-Zamudio, 2011 for details).

\section{RESULTS AND DISCUSSION}

\section{Distribution of the exotic weevil}

In total, we detected 48 adult Stenopelmus rufinasus across 17 temporary ponds. In these 17 ponds, Azolla filiculoides was not detectable, only occurring in two of the 91 sampled ponds. The exotic weevil was never detected in the southern portion of the park (Fig. 1), where water bodies are few and isolated (see Díaz-Paniagua et al., 2014). In the marsh, two individuals of the exotic weevil were also detected in May 2011, on leaves of $A$. filiculoides collected from the border of the marsh (Fig. 1). In contrast, during our study period, S. rufinasus was always recorded in ponds where the specific host plant, A. filiculoides, was not detectable. All specimens of $S$. rufinasus were collected in May-June, coinciding with the season when A. filiculoides was especially productive in the marsh (Fig. 2). Almost all specimens were recorded during 2006-2007, whereas its presence in 2005-2006 was limited to a single pond in May (Fig. 1 \& 2). The exotic weevil exhibits excellent dispersal abilities, as it has even been recorded up to $300 \mathrm{~km}$ from sites where it was released (Hill, 2003). Therefore, we suggest that the occurrence of $S$. rufinasus in the ponds of the park may reflect the seasonal high production of $A$. filiculoides in the marshes. From there, adult weevils could have dispersed to the pond network. This could explain the higher abundance of the exotic weevil in 2007 , which may be related to the higher production of A. filiculoides that year, most likely associated with higher rainfall $(2005-2006=468 \mathrm{~mm} v$ s. $2006-2007=717 \mathrm{~mm})$. A smaller number of 
ponds were formed in the park in 2005-2006 as a consequence of the low precipitation (Florencio et al., 2009), which could also have limited the occurrence of the exotic weevil in 2006, when it was only detected in a single pond.

\section{Comparison between exotic and native weevils}

In contrast to $S$. rufinasus, only a total of 16 individuals of native weevils (Bagous vivesi González, 1967, Bagous subcarinatus Gyllenhal, 1836 and Bagous revelierei Tournier, 1884) were collected, across 9 ponds and in different months (Fig. 1 \& 2). Although it has been shown that $S$. rufinasus can often occur at low density (Pemberton \& Bodle, 2009), we found that it was more frequent than any native aquatic weevil in our study ponds. Exotic and native weevils were detected in sites exhibiting high vegetation cover (approximately 80\% vegetated) of similar species of aquatic plants: Agrostis stolonifera, Panicum repens, Paspalum paspalodes, Juncus heterophyllus, Isolepis pseudosetaceus, Eleocharis palustris and Ranunculus peltatus. Native weevils occurred across different months in the study ponds, but the exotic weevil only occurred during May-June (Fig. 2) suggesting that $S$. rufinasus may complete its life cycle in the marshes, where A. filiculoides is abundant, only appearing in ponds after adult dispersal. In this sense, the presence of $A$. filiculoides could be essential for the exotic weevil's reproduction but not necessary for adult survival. Although A. filiculoides has been shown to be the most suitable host plant for feeding, oviposition and larval development for S. rufinasus (Hill, 1998), S. rufinasus has also been detected on other plant species (Carrapiço et al., 2011), suggesting that feeding on other plants cannot be completely excluded. The presence of both exotic and native weevils in similar aquatic plant assemblages showing dense vegetation cover strengthens this possibility. The establishment of the exotic weevil on native aquatic plants could constitute a potential source for further dispersal when $A$. filiculoides reappears following annual inundation (McConnachie et al., 2004). Our discovery of $S$. rufinasus at relatively high densities in apparently host-free ponds suggests that the species may utilise alternative hosts in southern Europe, at least as an adult. Although we cannot discard the possibility that these occurrences in host-free ponds constitute sink populations, such

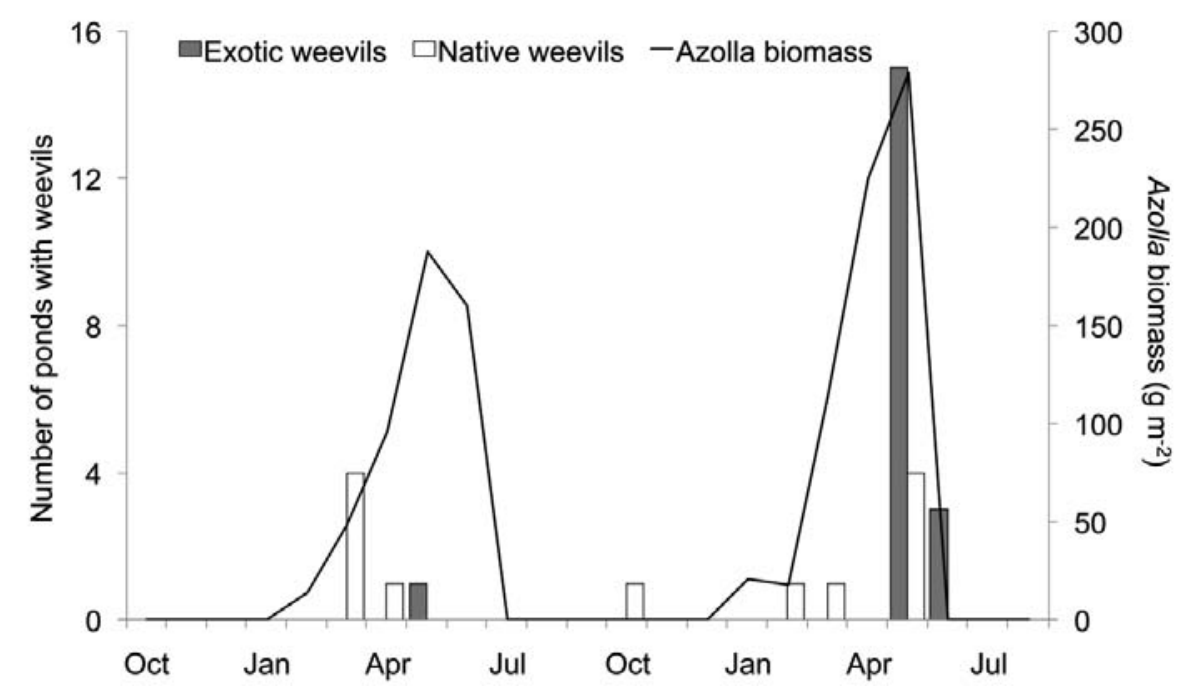

Figure 2. Number of ponds in the sandy area of Doñana National Park where native and exotic weevils were detected (from October, 2005 to August, 2007) and monthly Azolla filiculoides biomass $\left(\mathrm{g} / \mathrm{m}^{2}\right)$ collected in the marshes. Número de lagunas de las arenas estabilizadas del Parque Nacional de Doñana donde se detectaron las especies de gorgojo exótico y nativo (desde Octubre de 2005 hasta Agosto de 2007) y biomasa mensual de Azolla filiculoides $\left(\mathrm{g} / \mathrm{m}^{2}\right)$ recolectada en la marisma. 
populations may also represent an incipient case of niche shift following the introduction of an exotic species into a new area (Broennimann et al., 2007). However, such adult populations may themselves act as sources of colonists, host-free sites thus acting as stepping stones for the spread of this invasive species.

Sampling specifically designed to collect abundance data on $S$. rufinasus should be performed in the marshes to shed some light on its invasive potential. Further studies on these particular populations (e.g., demography, species distribution modelling, physiological competence experiments, propagule pressure) should be performed, as this is an interesting system for understanding invasion processes. Such studies may lead to the rethinking of the introduction of exotic species as biological control agents. $S$. rufinasus has been already used as a successful biological control agent against $A$. filiculoides in South Africa (Hill, 2003; Hill \& Julien, 2004), but its use in the United Kingdom has not had the same impact on the target plant (Gassmann et al., 2006), and it has not been specifically employed in other European regions to date. In the light of our findings, future uses of S. rufinasus as a control agent should be preceded by host specificity tests, including how well the species can persist on other possible host/intermediate plants (Pratt et al., 2013).

\section{ACKNOWLEDGEMENTS}

We are grateful to the research team of Javier Bustamante, especially to Ricardo Díaz-Delgado, for providing the two specimens of S. rufinasus collected over leaves of $A$. filiculoides coming from the border of the marsh in 2011. We are also grateful to Isabel Afán for her assistance in map formatting. We also would like to thank $\mathrm{Ca}$ rola Gómez-Rodríguez, Carlos Marfil, Alexandre Portheault, Azahara Gómez Flores, Reyes Lora and all those who helped with the fieldwork. We are also grateful to Project 158/2010- Ministerio Agricultura Alimentación y Medio Ambiente; to the Direcção Regional da Ciência, Tecnologia e Comunicações (DRCT) for supporting the current fellowship of M.F. (M3.1.7/F/002/2011); and to the two anonymous referees for improvements to this manuscript.

\section{REFERENCES}

BEDEL, L. 1901. Description et moeurs d'un Nouveau genre de Curculionides de France. Bulletin de la Société Entomologique de France, 6: 358-359.

BROENNIMANN, O., U. A. TREIER, H. MÜLLERSCHÄRER, W. THUILLER, A. T. PETERSON \& A. GUISAN (2007) Evidence of climatic niche shift during biological invasion. Ecology Letters, 10(8): 701-709.

CARRAPIÇO, F., R. SANTOS \& A. SERRANO. 2011. First Occurrence of Stenopelmus rufinasus Gyllenhal, 1835 (Coleoptera: Erirhinidae) in Portugal. The Coleopterists Bulletin, 65: 436-437.

DANA, D. \& S. VIVA. 2006. Stenopelmus rufinasus Gyllenhal 1836 (Coleoptera: Erirhinidae) Naturalized in Spain. The Coleopterists Bulletin, 60(1): 41-42.

DÍAZ-PANIAGUA, C., C. KELLER, M. FLORENCIO, A. C. ANDREU, A. PORTHEAULT, C. GÓMEZ-RODRÍGUEZ \& I. GÓMEZ-MESTRE. 2014. Rainfall stochasticity controls the distribution of invasive crayfish and its impact on amphibian guilds in Mediterranean temporary waters. Hydrobiologia, 728(1): 89-101.

FERNÁNDEZ CARRILLO, J. L., E. FERNÁNDEZ CARRILLO \& M. A. ALONSO-ZARAZAGA. 2005. Primera cita de Stenopelmus rufinasus Gyllenhal, 1835 en la Península Ibérica (Coleoptera, Erirhinidae). Graellsia, 61: 139-140.

FERNÁNDEZ-ZAMUDIO, R. 2011. Plantas acuáticas del Parque Nacional de Doñana: aspectos ecológicos y biología de una especie exótica. Ph.D. Thesis, University of Seville, Seville.

FLORENCIO, M., L. SERRANO, C. GÓMEZ-RODRÍGUEZ, A. MILLÁN \& C. DÍAZ-PANIAGUA. 2009. Inter and intra-annual variations of macroinvertebrate assemblages are related to the hydroperiod in Mediterranean temporary ponds. Hydrobiologia 634: 167-183.

FLORENCIO, M., C. DÍAZ-PANIAGUA, L. SERRANO \& D. T. BILTON. 2011. Spatio-temporal nested patterns in macroinvertebrate assemblages across a pond network with a wide hydroperiod range. Oecologia, 166: 469-483. 
GARCÍA-MURILLO, P., R. FERNÁNDEZ-ZAMUDIO, S. CIRUJANO, A. SOUSA \& J. M. ESPINAR. 2007. The invasion of Doñana National Park (SW Spain) by the mosquito fern (Azolla filiculoides Lam.). Limnetica, 26: 243-250.

GASSMANN, A., M. J. W. COCK, R. SHAW \& H. C. EVANS. 2006. The potential for biological control of invasive alien aquatic weeds in Europe: a review. Hydrobiologia, 570: 217-222.

HILL, M. P. 1998. Life history and laboratory host range of Stenopelmus rufinasus, a natural enemy for Azolla filiculoides in South Africa. BioControl, 43: 215-224.

HILL, M. P. 2003. The impact and control of alien aquatic vegetation in South African aquatic ecosystems. African Journal of Aquatic Science, 28: 19-24.

HILL, M. P. \& M. H. JULIEN. 2004. The transfer of appropriate technology; key to the successful biological control of five aquatic weeds in Africa. In: Proceedings of the XI International Symposium on Biological Control of Weeds. J. M. Cullen, D. T. Briese, D. J. Kriticos, W. M. Lonsdale, L. Morin, J. K. Scott (eds): 351-352. CSIRO Entomology, Canberra, Australia.
MCCONNACHIE, A. J., M. P. HILL \& M. J. BYRNE. 2004. Field assessment of a frond-feeding weevil, a successful biological control agent of red waterfern, Azolla filiculoides, in southern Africa. Biological Control, 29: 326-331.

PAN-EUROPEAN SPECIES DIRECTORIES INFRASTRUCTURE (PESI) CALDARA R. Stenopelmus rufinasus Gyllenhal, 1835. Accessed 22/ 10/2014 through: Fauna Europaea at http://www. faunaeur.org/full_results.php?id=217921

PEMBERTON, R. W. \& J. M. BODLE. 2009. Native North American Azolla weevil, Stenopelmus rufinasus (Coleoptera: Curculionidae), uses the invasive old world Azolla pinnata as a host plant. Florida Entomologist, 92: 153-155.

PRATT, C. F., R. H. SHAW, R. A. TANNER \& J. G. M. DJEDDOUR. 2013. Biological control of invasive non-native weeds: An opportunity not to be ignored. Entomologische Berichten, 73: 144-154.

RICHERSON, P. J. \& A. A. GRIGARICK. 1967. The life history of Stenopelmus rufinasus, (Coleoptera: Curculionidae). Annals of the Entomological Society of America, 60: 351-354.

SCULTHORPE, D. 1967. The biology of aquatic vascular plants. Edward Amold Ltd, London. 